\title{
Konkurencyjność i innowacyjność regionów Unii Europejskiej - analiza porównawcza
}

Ewa Hamerla*

\section{Wstęp}

Szeroko rozumiany rozwój państw członkowskich jest jednym z głównych celów Unii Europejskiej. Do osiągania coraz lepszych wyników gospodarczych powinny dążyć zarówno poszczególne kraje, jak i Europa jako całość, a jednym z najważniejszych elementów polityki spójności jest wyrównywanie dysproporcji w rozwoju państw członkowskich.

Innowacje odgrywają ważną rolę w pobudzaniu wzrostu gospodarczego na poziomie państwa oraz regionu, a jeśli chodzi o przedsiębiorstwa, to uznawane są za podstawowy czynnik ich rozwoju i osiągania przewagi konkurencyjnej (Geodecki 2016, s. 182-183).

W niniejszym artykule podjęto próbę odpowiedzi na pytanie o to, jaki jest poziom konkurencyjności poszczególnych regionów Unii Europejskiej oraz w jakim stopniu innowacyjność państw członkowskich Unii Europejskiej wpływa na poziom ich konkurencyjności. Podjęta zostanie również próba oceny poziomu rozwoju państw członkowskich na podstawie analizowanych danych. Do sformułowania odpowiedzi na te pytania wykorzystano metodę indukcji i dedukcji oraz analizę literatury przedmiotu, ze szczególnym uwzględnieniem danych Eurostatu i „Europejskiej tablicy wyników innowacji”.

\footnotetext{
* Ewa Hamerla - magister, Uniwersytet Łódzki, Wydział Ekonomiczno-Socjologiczny, Katedra Gospodarki Światowej i Integracji Europejskiej, h.ewa@poczta.fm.
} 


\section{Konkurencyjność regionów Unii Europejskiej}

Wyrażenie „regiony Unii Europejskiej” można pojmować w różny sposób - państwa członkowskie są pewnego rodzaju regionami, lecz dzielą się one na kolejne obszary, tworząc następne regiony. Konkurencyjność można zatem odnosić zarówno do całych państw, jak i ich regionów.

Konkurencyjność to złożone pojęcie, które nie ma jednoznacznej definicji. Jedną z prostszych definicji przestawia J. Bunewicz, określając konkurencyjność jako zdolność do skutecznego przeciwstawiania się konkurencji (Dołęgowski 2016, s. 11). J. Zagórny odnosi pojęcie konkurencyjności do takich działań podejmowanych przez podmioty, które będą dla nich najkorzystniejsze pod względem uzyskania największego poziomu dochodu realnego (Zagórny 1947, s. 4). Inni naukowcy określają konkurencyjność jako zdolność podmiotów działających na danym obszarze do umiejętnego poruszania się na arenie konkurencji (Stankiewicz 2005, s. 36). Przytoczone definicje są podobne, choć widać w nich też pewne różnice.

Poziom konkurencyjności gospodarki zależy od poziomu konkurencyjności jej regionów, a poziom konkurencyjności regionów - od podmiotów działających na tych właśnie terenach. Nie ma jednego najlepszego sposobu na zmierzenie poziomu konkurencyjności, lecz można wyodrębnić grupy czynników, które mają znaczny wpływ na ten właśnie aspekt. Wskaźnik RCI (Regional Competitiveness Index), oparty na regionach NUTS 2 (Nomenclature des unités territoriales statistiques), poszerza ekonomiczną analizę konkurencyjności regionów o aspekty społeczne - w tym przypadku wspierane są problematyczne regiony o niskim poziomie rozwoju. RCI opiera się na toczącej się obecnie debacie o tym, że miara dobrobytu powinna wykraczać poza PKB. Należałoby wziąć pod uwagę takie czynniki jak rozwój służby zdrowia czy kapitał ludzki (Eurostat: Regional competitiveness statistics). Na ogólną wartość wskaźnika RCI składa się 11 podkategorii, które są dodatkowo pogrupowane w subindeksy:

1. Subindeks podstawowy: instytucje państwowe; stabilność makroekonomiczna; infrastruktura; dobry stan zdrowia ludności.

2. Subindeks efektywności: szkolnictwo wyższe, szkolenie i uczenie się przez całe życie; wydajność rynku pracy; wielkość rynku.

3. Subindeks innowacji: gotowość technologiczna; wyrafinowanie biznesowe; innowacje (Eurostat: Regional competitiveness statistics).

Rysunek 1 prezentuje pełen obraz różnic w poziomie konkurencyjności poszczególnych regionów Unii Europejskiej w roku 2016. 
Rysunek 1. Różnice w poziomie konkurencyjności regionów w Unii Europejskiej. RCI według NUTS 2 z roku $2016($ EU-28 = 0)

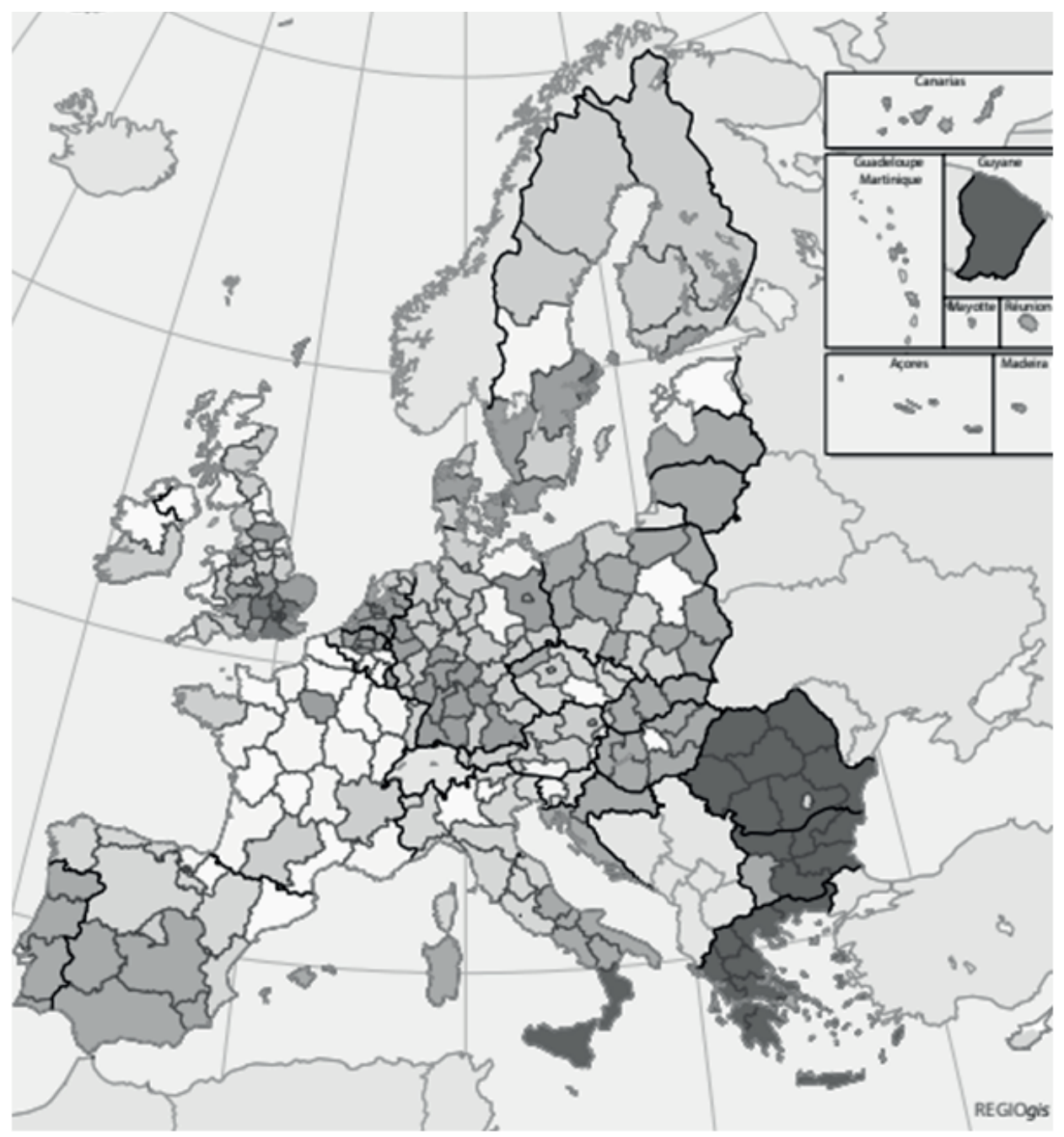

Regional Competitiveness Index - RCI 2016

Index: values range from low (negative) to high (positive)

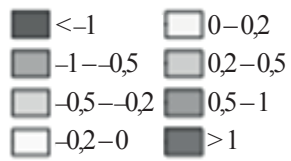

$\mathrm{EU}-28=0$

Source: DG REGIO

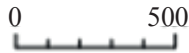

Źródło: The EU Regional Competiveness Index 2016, „Working Papers”, nr 02, 2017, s. 4.

Z powyższego rysunku wynika, że najbardziej konkurencyjnymi regionami są zachodnie Niemcy, Niderlandy, region Paryża, Południowa Anglia oraz połu- 
dniowa Szwecja i Finlandia. Najmniej konkurencyjne są regiony Grecji, Bułgarii, Rumunii i południowych Włoch. Zamieszczone poniżej tabele 1 i 2 zawierają bardziej szczegółowe dane.

Tabela 1 przedstawia dziesięć najlepszych pod względem konkurencyjności regionów w Europie w roku 2016. Zestawienie przygotowano na podstawie znormalizowanych wyników, zgodnie z którymi region z najwyższym RCI otrzymał 100 punktów, a region z najniższym wskaźnikiem RCI - 0 .

Tabela 1. Dziesięć najbardziej konkurencyjnych regionów Unii Europejskiej w 20016 roku

\begin{tabular}{|c|c|c|}
\hline & Region (NUTS kod) & RCI 2016 \\
\hline 1 & Londyn i okolice (UKH2, UKH3, UKI1, UKI2) & 100,00 \\
\hline 2 & Berkshire, Buckinghamshire and Oxfordshire (UKJ1) & 97,67 \\
\hline 2 & Utrecht (NL31) & 97,63 \\
\hline 4 & Stockholm (SE11) & 97,21 \\
\hline 5 & Surrey, East and West Sussex (UKJ2) & 93,95 \\
\hline 6 & Hovedstaden (DK01) & 92,94 \\
\hline 7 & Luxembourg (LU 00) & 91,06 \\
\hline 8 & Île de France (FR10) & 90,27 \\
\hline 9 & Oberbayern (DE21) & 89,68 \\
\hline 10 & Hampshire and Isle of Wight (UKJ3) & 88,61 \\
\hline
\end{tabular}

Źródło: opracowanie własne na podstawie The EU Regional Competiveness Index 2016, „Working Papers" nr 02, 2017, s. 5.

Regiony Wielkiej Brytanii występują w pierwszej dziesiątce aż kilka razy, co świadczy o wysokim poziomie konkurencyjności tych obszarów, a to przekłada się na bardzo dobrą kondycję całego państwa pod względem konkurencyjności. Trzecie miejsce zajmuje należący do Holandii Utrecht. Na kolejnych pozycjach są Sztokholm i regiony Danii, Luksemburgu, Francji oraz Niemiec. Warto jednak zwrócić uwagę na to, że Wielka Brytania rozpoczęła procedurę wyjścia z Unii Europejskiej, zatem można przypuszczać, że powyższe dane ulegną dużym zmianom.

Większość przedstawionych w tabeli 1 regionów to regiony stolic wymienionych państw, co tłumaczy ich bardzo dobre wyniki. Wniosek ten można wyciągnąc na podstawie teorii rozwoju regionalnego dotyczącej skupisk (aglomeracji), teorii gron i nowych okręgów przemysłowych (zob. Jewtuchowicz 2013, s. 130; Olejniczak 2003, s. 59-62). We wspomnianych teoriach duże aglomeracje miejskie, grona czy też okręgi przyczyniają się zarówno do wysokiego poziomu konkurencyjności, jak i rozwoju danych regionów.

Tabela 2 przedstawia dziesięć najsłabszych pod względem konkurencyjności regionów Unii Europejskiej w 2016 roku. 
Tabela 2. Dziesięć najmniej konkurencyjnych regionów Unii Europejskiej w 2016 roku

\begin{tabular}{|c|c|c|}
\cline { 2 - 3 } \multicolumn{1}{l|}{} & Region (NUTS kod) & RCI 2016 \\
\hline 254 & Sud-Muntenia (RO31) & 5,69 \\
\hline 255 & Sud-Vest Oltenia (RO41) & 5,56 \\
\hline 256 & Ionia Nisia (EL62) & 4,87 \\
\hline 257 & Dytiki Ellada (EL63) & 3,18 \\
\hline 258 & Peloponnisos (EL25) & 1,95 \\
\hline 258 & Severozapaden (BG31) & 1,89 \\
\hline 258 & Sterea Ellada (EL64) & 1,84 \\
\hline 261 & Anatoliki Makedonia, Thraki (EL51) & 0,20 \\
\hline 262 & Sud-Est (RO22) & 0,07 \\
\hline 262 & Guyane (FRA3) & 0,00 \\
\hline
\end{tabular}

Źródło: opracowanie własne na podstawie The EU Regional Competiveness Index 2016, „Working Papers", nr 02, 2017, s. 5.

Z danych zamieszczonych w tabeli 2 wynika, że większość najmniej konkurencyjnych regionów znajduje się w Grecji. W tej grupie są także regiony Bułgarii i Rumunii oraz region Francji, choć warto podkreślić, że region ten nie znajduje się na kontynencie europejskim.

Główny wskaźnik RCI w regionie Utrecht wynosi 1,36 (pierwszy region po Wielkiej Brytanii, której członkostwo w Unii Europejskiej jest niepewne). W przypadku polskich województw wynosi on średnio -0,62 (obliczenia własne na podstawie Eurostat - competitiveness statistics). Z tego porównania można wnioskować, że pod względem konkurencyjności różnica między regionami Polski a jednym z najbardziej konkurencyjnych regionów Unii Europejskiej jest duża. Dla porównania można dodać, że w najmniej konkurencyjnym regionie Bułgarii (Severozapaden) wskaźnik ten wynosi-1,47 (Eurostat - competitiveness statistics). Na podstawie tych danych regiony Polski można zatem ocenić jako umiarkowanie konkurencyjne.

Konkurencyjność, jak już wspomniano, jest bardzo złożonym pojęciem. Duży wpływ na jej wartość ma innowacyjność. Istnieje pewna relacja między konkurencyjnością a innowacyjnością, wskazująca na to, że to drugie pojęcie jest składową pierwszego (Kowalik 2015, s. 27).

\section{Innowacyjność państw członkowskich Unii Europejskiej}

Innowacyjność jest bardzo szerokim pojęciem, które zmieniało się z biegiem czasu z powodu ewolucyjnego otoczenia, a także technologii, której bardzo często dotyczą same innowacje (Kedia, Jain 2013, s. 289). Innowacyjność jest zdolno- 
ścią do wdrażania nowych lub istotnie zmienionych procesów, produktów czy usług. Może ona dotyczyć różnych branż w obszarach marketingowych, organizacyjnych („Nauka i technika” 2013, s. 25).

Innowacyjność można rozpatrywać na trzech płaszczyznach: państwa, regionu i przedsiębiorstwa. Wszystkie te elementy mają na siebie bezpośredni wpływ. Na poziom innowacyjności regionu będą miały wpływ przedsiębiorstwa działające na tych właśnie terenach. Mierząc zatem innowacyjność przedsiębiorstw, warto badać sposób, w jaki wprowadzana są te innowacje, analizować środki, jakie są na nie przeznaczane, czy też to, czego innowacje dotyczą. Innowacyjność firmy oddziałuje na jej otoczenie i inne przedsiębiorstwa działające na rynku, a dalej na cały region. W efekcie cała gospodarka może stać się bardziej innowacyjna (Kowalik 2015, s. 27).

The Regional Innovation Scoreboard (RIS) („Regionalna tablica wyników innowacyjności”), jako regionalna wersja „Europejskiej tablicy wyników innowacyjności”, ocenia innowacyjność europejskich regionów w oparciu o ograniczoną liczbę wskaźników. RIS 2017 obejmuje 220 regionów w 22 krajach UE oraz w Norwegii, Serbii i Szwajcarii. W zestawieniu zostały uwzględnione także: Cypr, Estonia, Łotwa, Litwa, Luksemburg i Malta (na poziomie krajowym).

RIS 2017 powiela udoskonalone ramy analityczne „Europejskiej tablicy wyników innowacji” pod względem dostępności danych. Ponadto wprowadza bardziej szczegółowy podział grup wydajności i oferuje nowy zestaw narzędzi z danymi kontekstowymi, które można wykorzystać do analizy i porównania różnic strukturalnych między regionami (https://ec.europa.eu/growth/industry/innovation/facts-figures/regional_en).

Rysunek 2 (s. 154) przedstawia Unię Europejską w podziale na regiony z uwzględnieniem ich innowacyjności w 2017 roku według RIS. Z rysunku wynika, że regiony charakteryzujące się większą innowacyjnością znajdują się w północno-zachodniej części Unii Europejskiej, z wyłączeniem regionów Hiszpanii i Portugalii. Szczególnie wysoki poziom innowacyjności prezentują regiony Wielkiej Brytanii, Szwecji, Finlandii, Niemiec, Holandii i Danii, a najniższy - regiony Bułgarii, Rumuni i Polski.

Najbardziej innowacyjnym regionem w Unii Europejskiej jest Sztokholm w Szwecji, a następnie Hovedstaden (Kopenhaga) w Danii i południowo-wschodnia część Wielkiej Brytanii. Niektóre regionalne ośrodki innowacyjne funkcjonują również w krajach o umiarkowanym poziomie innowacyjności: Praga w Republice Czeskiej, Bratysława na Słowacji i Kraj Basków w Hiszpanii (https:// ec.europa.eu/growth/industry/innovation/facts-figures/regional_en).

Różnice między poszczególnymi krajami wynikają również z ich potencjału innowacyjnego. Dla państw takich jak Rumunia czy Bułgaria ważniejsze jest wyprodukowanie odpowiedniej ilości produktów, a dopiero później praca nad ich jakością. Oczywiście można mówić o powiązaniu tych procesów, lecz priorytety są różne. Motywacja do podejmowania działań innowacyjnych jest bardzo istotna, 
a gdy jej nie ma, trudno mówić o innowacyjności. Innowacyjność nawiązuje do ciągłego rozwijania się, poszukiwania nowych rozwiązań, technologii i koncepcji, a także doskonalenia już istniejących pomysłów. Wiele danych pokazuje jej bezpośredni związek z poziomem rozwoju przedsiębiorstw czy całych regionów (Olejniczak 2003, s. 58).

Rysunek 2. Innowacyjność regionów Unii Europejskiej w 2017 roku z podziałem na regiony RIS

$\bullet \bullet \bullet$ Innovation leaders

$\bullet$ Strong innovators

- Moderate innovators

$\bullet \bullet$ Modest innovators

$-+$

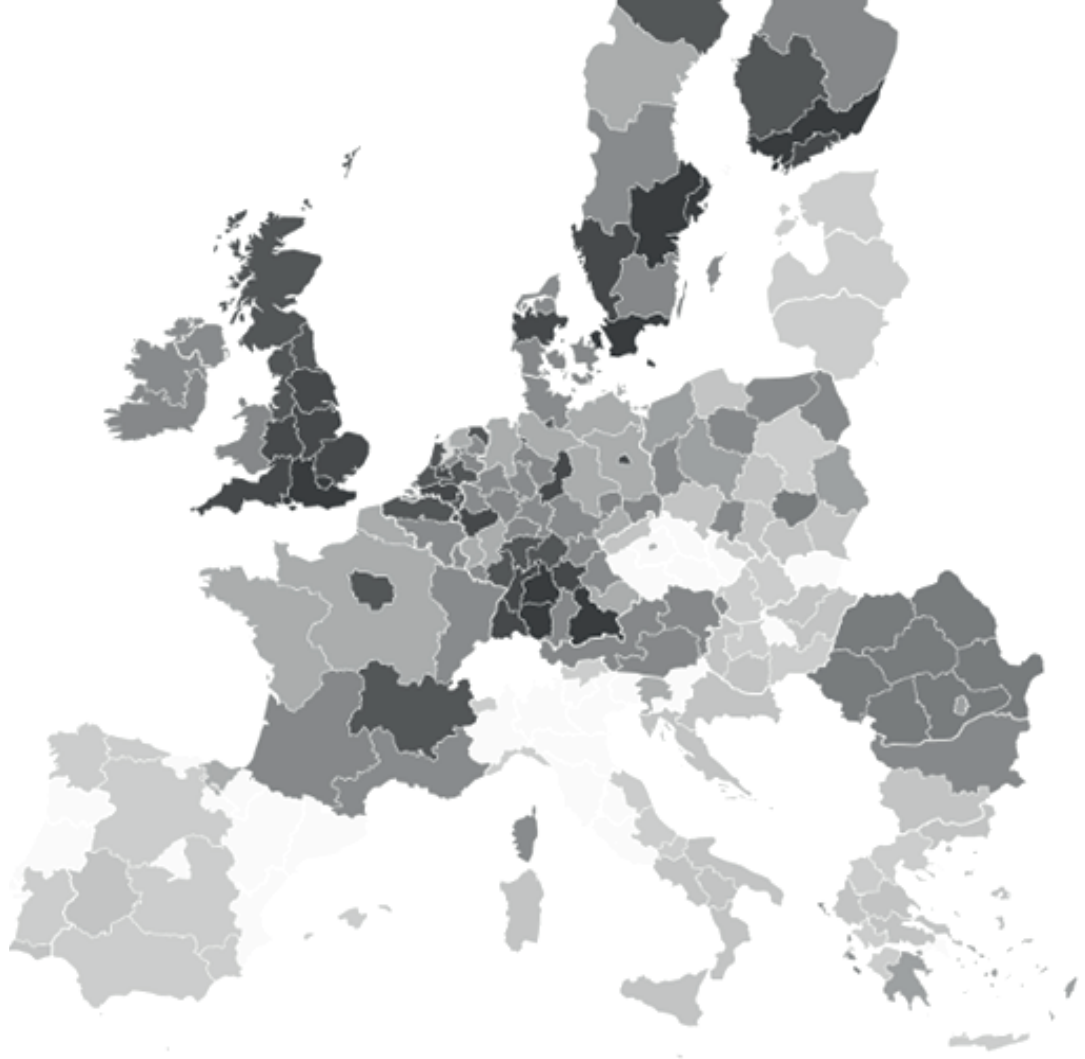

Źródło: The European Innovation scoreboard indicators, https://ec.europa.eu/growth/industry/innovation/facts-figures/regional_en. 


\section{Rozwój regionów Unii Europejskiej a ich konkurencyjność i innowacyjność}

Konkurencyjność ma pozytywny wpływ na rozwój. Pobudza kreatywność podmiotów i wspomaga ich innowacyjność (Mundschenk 2006, s. 3-6). Występowanie subindeksu innowacji jako elementu indeksu RCI sugeruje ścisłe powiązanie tych kategorii. Można zatem wnioskować, że innowacje są czynnikiem sprzyjającym konkurencyjności. Wpływ innowacyjności i konkurencyjności na regiony został szerzej ujęty w jednej z nowszych teorii rozwoju regionalnego dotyczącej gron (klastrów). Według M.E. Portera, twórcy tej teorii, grona to „geograficzne skupiska wzajemnie powiązanych firm, wyspecjalizowanych dostawców, jednostek świadczących usługi, firm działających w pokrewnych sektorach i związanych z nimi instytucji (np. uniwersytetów, jednostek normalizacyjnych i stowarzyszeń branżowych) w poszczególnych dziedzinach, konkurujących między sobą, ale także współpracujących" (Porter 2001, s. 246). To właśnie wspominane czynniki (ujęte we wskaźniku RCI) są w tym ujęciu podstawą rozwoju regionu.

Przyjmując, że regionami Unii Europejskiej są jej państwa członkowskie, można rzec, że konkurowanie odnosi się do międzynarodowej rywalizacji. W tym ujęciu najbardziej konkurencyjne są regiony Holandii, Francji, Niemiec, Szwecji oraz Danii, zaś najmniej konkurencyjne - regiony Grecji, Bułgarii oraz Rumunii. Najbardziej innowacyjne państwa to Finlandia, Szwecja, Niemcy i Dania, a najniższy poziom innowacyjności osiągnęły Bułgaria, Rumunia, Łotwa i Polska.

Na rysunkach 1 i 2 widać pewne zbieżności między regionami o wysokim poziomie innowacyjności i konkurencyjności. Holandia, która z roku na rok poprawia swoją pozycję wśród najbardziej innowacyjnych państw członkowskich, plasuje się również na wysokiej pozycji, jeśli chodzi o poziom konkurencyjności (Eurostat - The European Innovation scoreboard indicators; Eurostat - competitiveness statistics). Ponieważ wspomniane czynniki (konkurencyjność ujęta we wskaźniku RCI oraz innowacyjność) są jednymi z ważniejszych w określaniu poziomu rozwoju regionów, można przyjąć, że Holandia, Dania i Niemcy są jednymi z najbardziej rozwiniętych krajów Unii Europejskiej. Tuż za nimi plasują się Finlandia i Szwecja. Przypadek Wielkiej Brytanii należy rozpatrywać bardziej indywidualnie ze względu na rozpoczętą procedurę jej wystąpienia z Unii Europejskiej. Z rysunków 1 i 2 wynika, że jest ona najlepiej rozwijającym się krajem Europy.

\section{Podsumowanie}

Podjęta w artykule próba oceny stopnia rozwoju państw europejskich na podstawie poziomu ich konkurencyjności oraz innowacyjności ukazała wyraźne powiązanie między tymi czynnikami a rozwojem regionów (rozumianych jako kraje członkowskie Unii Europejskiej). 
Analizując dane statystyczne Eurostatu, dojść można do wniosku, że najlepiej rozwijającymi się państwami Unii Europejskiej są Holandia, Dania, Niemcy i Finlandia, zaś jednymi z najmniej rozwiniętych Rumunia, Bułgaria i Grecja. Polska jest jednym ze słabiej rozwijających się krajów.

W analizie nie można zapomnieć o tym, że Wielka Brytania rozpoczęła procedurę wyjścia z Unii Europejskiej, co wpłynie na statystyki dotyczące konkurencyjności i innowacyjności, zmieniając pozycje danych państw. Nie zaburza to jednak oceny wspomnianych czynników pozostałych krajów. Widoczne są zarówno relacje między innowacyjnością a konkurencyjnością, jak i tymi czynnikami oraz poziomem rozwoju poszczególnych państw.

\section{Bibliografia}

Dołęgowski T. (2016), Międzynarodowa konkurencyjność gospodarki a solidarność. Dobro wspólne i jakość, Oficyna Wydawnicza SGH, Warszawa.

Europa.eu, https://ec.europa.eu/growth/industry/innovation/facts-figures/regional_en (dostęp: 23.03.2018).

Eurostat, http://ec.europa.eu/eurostat/statisticsexplained/index.php/Regional competitiveness_statistics\#Regional_competitiveness_gaps_within_the same_country_.E2.80.94_harmful_for_national_competitiveness.3F (dostęp: 2.04.2018).

Geodecki T. (2016), Polityka wsparcia konkurencyjności gospodarki, Polskie Wydawnictwo Ekonomiczne, Warszawa.

GUS (2013), Nauka i technika w 2013 r., Warszawa.

Jewtuchowicz A. (2013), Terytorium $i$ wspótczesne dylematy jego rozwoju, Wydawnictwo Uniwersytetu Łódzkiego, Łódź.

Kedia B.L., Jain S.C. (2013), Restoring America's Global Competitiveness through Innovation, Edward Elgar Publishing, Cheltenham, UK and Northampton, MA, USA.

Komisja Europejska, The EU Regional Competiveness Index 2016, „Working Papers", nr 02, 2017.

Kowalik J. (2015), Analiza poziomu innowacyjności państw europejskich, „Zeszyty Naukowe Politechniki Częstochowskiej”, „Zarządzanie” nr 19.

Mundschenk S., Stierle M.H., Stierle von Schütz U., Traistaru I. (2006), Competitiveness and growth in Europe. Lesson and Policy Implication for the Lisbon Strategy, Edward Elgar Publishing, Cheltenham, UK and Northampton, MA, USA.

Olejniczak K. (2003), Apetyt na grona? Koncepcja gron oraz koncepcje bliskoznaczne $w$ teorii i praktyce rozwoju regionalnego, „Studia Regionalne i Lokalne" nr 2(12). 
Porter M.E. (2001), Porter o konkurencji, Polskie Wydawnictwo Ekonimiczne, Warszawa.

Stankiewicz M.J. (2005), Konkurencyjność przedsiębiorstwa. Budowanie konkurencyjności przedsiębiorstwa w warunkach globalizacji, wyd. II, TONiK „Dom organizatora”, Torun.

Zagórski J. (1947), Ogólna teoria konkurencji, Wydawnictwo Kazimierza Rudskiego, Warszawa - Łódź.

Żbikowski J. (2015), Konkurencyjność jednostek samorzadu terytorialnego. Wybrane problemy, „Handel wewnętrzny” nr 4(357).

\section{Streszczenie}

Konkurencyjność to bardzo szerokie pojęcie. Jedni naukowcy wiążą silnie jej definicję z efektywnością ekonomiczną, inni z innowacyjnością, a są również tacy, którzy jej charakter pojęciowy będą uzależniać od otoczenia, w jakim może ona występować na rynku. Konkurencyjność można ująć zarówno w skali mikro (w przypadku pojedynczych przedsiębiorstw czy branż), jak i w skali makro (w tym przypadku będzie się ona odnosić do całych państw). Poziom konkurencyjności jest często uznawany za jeden z podstawowych czynników rozwoju gospodarczego państw (Żbikowski, s. 38 ).

Głównym wskaźnikiem mierzącym poziom konkurencyjności regionów i krajów Unii Europejskiej jest indeks RCI (Regional Competitiveness Index). Na jego podstawie możemy wyciągnąć pewne wnioski dotyczące ich rozwoju. Celem niniejszych rozważań jest udzielenie odpowiedzi na pytania o to, jaki jest poziom konkurencyjności poszczególnych regionów Unii Europejskiej oraz w jakim stopniu innowacyjność państw członkowskich Unii Europejskiej wpływa na poziom ich konkurencyjności. W artykule podjęto również próbę ocenienia poziomu rozwoju państw członkowskich na podstawia analizowanych danych.

Słowa kluczowe: konkurencyjność, innowacyjność, rozwój, region

\section{Summary}

The competitiveness and innovation of European Union regions

- a comparative analysis

Competitiveness is a very broad concept. Some scientists define it with the emphasis on economic efficiency, others on innovativeness, and there are also those who will characterize its conceptual character from the environment in which it can appear on the market. Competitiveness can be captured both on a micro scale 
- in relation to individual enterprises or industries, as well as on a macro scale - in relation to entire countries. Often, one of the basic factors of a country's economic development is its level of competitiveness.

The RCI Index (Regional Competitiveness Index) is the main indicator measuring the level of competitiveness European Union countries and regions. On its basis, we can draw some conclusions about their development. The aim of the paper is to answer the question of what the level of competitiveness of individual regions of the European Union is and how much innovation in the European Union Member States affects their level of competitiveness. An attempt will be made to assess the level of development of the Member States on the basis of the analysed data.

Keywords: competitiveness, innovation, development, region

JEL: O20, O30, F01 